\title{
The Role and Authority of Notaries in the Making of a Marriage Agreement in Positive Law in Indonesia
}

\author{
Kunti Tri Pertiwi ${ }^{1} \quad$ Salim $\mathrm{HS}^{2} \quad$ Aris Munandar $^{2}$ \\ 1.Graduate Program Student in Notary, Faculty of Law, Mataram University, Indonesia \\ 2.Lecturer of Faculty of Law, Mataram University, Indonesia
}

\begin{abstract}
This Study discusses of the Constitutional Court Number 69 / PUUXIII / 2015 and the authority of a notary public in drafting a marriage agreement after the Decision of the Constitutional Court Number 69 / PUU-XIII / 2015 regarding a marriage agreement that can be made based on marriage, then immediately the Constitutional Court's decision is contrary to the book of Law Civil Procedures Articles 149, 1320, and 1338. The results of the discussion of this scientific article are the Constitutional Court Decision Number 69 / PUU-XIII / 2015 which allows the making of marriage can be done only before marriage as done in the Marriage Law Number 1 Year 1974 regarding Marriage and Article 147 of the Civil Code Book can be made or carried out in accordance with the marriage agreement after marriage, the limits of Notary Authority according to this Law in Article 15 paragraph (1), as well
\end{abstract} as in carrying out their duties the notary must refer to Article 16 paragraph (1).

Keywords: The Role and authority of the Notary, The Marriage Agreement, The Constitutional Court's Decision No. 69 / PUU-XIII / 2015

DOI: $10.7176 / \mathrm{JLPG} / 98-11$

Publication date:June 30th 2020

\section{Introduction}

Marriage is a bond that gives birth to the family as the basis of community and state life. In order to realize the prosperity and happiness of the community, there needs to be a solid and strong foundation as a starting point for a just and prosperous society, this is set forth in a UUP that applies to all citizens in the territory of the Unitary Republic of Indonesia.

As stated in Article 1 of Law Number 1 of 1974 concerning Marriage it is stated that ${ }^{1}$ : "Marriage is an inner and spiritual bond between a man and a woman as a husband in order to form a happy and eternal family (household) based on the Godhead of the Almighty ".

In the Compilation of Islamic Law in Article 2 it is stated that ${ }^{2}$ marriage in Islam is marriage, which is a very strong contract or mitsaqan ghalizhan to obey God's commands and carry out them is worship. According to Ahmad Azhar Basyir, marriage is an agreement or agreement to bind oneself between a man and a woman to justify sexual relations between the two parties, on a voluntary basis to realize a happiness in family life that is filled with love and peace with ways that are blessed by Allah. ${ }^{3}$

According to Sudikno Mertokusomo defines a marriage agreement as an agreement made before the marriage takes place and binds both the bride and groom to be married and takes effect after the marriage takes place. ${ }^{4}$

As a result of marriage to husband and wife property according to Civil Code is a unified mixed asset in Article 119 of the Civil Code assets obtained during marriage become joint property covering all marital assets, namely: assets that already existed at the time of marriage, assets obtained during marriage.

Marriage property is regulated in Book I of the Civil Code, because marital property as a result of marriage is included in the scope of family law. Marriage property law is not included in the scope of property law, although it is also related to property or material rights and material rights, therefore it is not regulated in Book III of the Civil Code Book on Engagement. Elisabeth Nurhaini Butarbutar said that "the regulation of marital property is not included in the scope of property law due to the assumption that marriage is not one way to obtain or obtain property or wealth, although it is recognized that marriage will result in one's position on property". ${ }^{5}$

Marriage agreements can also contain things that are feared to cause problems during the marriage, as well as if there is a marriage breakup. For example about monogany, about the personal right to choose a family name, about the rights and obligations of a husband and wife in marriage, about the work of each husband and wife, about the parties who are not allowed to do domestic violence, about their respective responsibilities towards children born into a marriage. In other words, husband and wife have a free but limited agreement to determine

\footnotetext{
${ }^{1}$ Indonesia Undang-Undang No. 1 Tahun 1974 Tentang Perkawinan Lembaran Negara No. 1 Tambahan Lembaran Negara No 3019

${ }^{2}$ Instruksi Presiden No.1 Tahun 1991 tentang Kompilasi Hukum Islam

${ }^{3}$ Ahmad Azhar Basyir, Hukum Perkawia Islam. FH UII, Ygyakarta, 2002. Hal. 11

${ }^{4}$ Sudikno Mertokusumo, Hukum Acara Perdata di Indonesia, Liberty, Yogyakarta, 1988. hal. 97

${ }^{5}$ Elisabeth Nurhaini Butarbutar, Hukum Harta Kekayaan: Menurut Sistematika KUH Perdata dan Perkembangannya, Refika Aditama, Bandung, 2012, hlm. 22
} 
the contents of the marriage agreement. ${ }^{1}$

Prenuptial agreements are mostly made as a separation of property, both assets obtained before the marriage takes place and assets obtained after marriage, the making must also be done before the marriage by a Notary, then recorded at the Office of Religious Affairs (KUA) (for Muslims) or to the Civil Registry (for the Civil Registry (KUA) for non-Muslims) and register it at the local district court.

Article 29 Paragraph (2) of Law No. 1 of 1974 concerning Marriage reads: "The agreement cannot be ratified if it violates the limits of law, religion and decency".

The marriage agreement is a means to protect the property of the bride and groom. Through this agreement the parties can determine their respective property. Is there a separation of assets in the marriage from the beginning or is there a shared asset, but how is the distribution divided if a divorce occurs. The inheritance of each husband and wife and property obtained as a gift or inheritance, are under the control of each other as long as the parties do not determine otherwise.

One of the disputes that must arise as a result of a marriage breakup is joint property that must be shared between husband and wife, because the property arises after the marriage. So with the increasing number of divorces in Indonesia, people's desire to make a marriage agreement also develops as more people realize that marriage is also a financial commitment such as the importance of the love relationship itself.

Separation or incorporation of assets at the time of marriage in the civil law code is different from the marriage law. The concept of marriage assets according to the Civil Code is the union of property, as contained in article 119 which reads "starting when the marriage takes place, by law a unified act of union between husband and wife's assets, only regarding that with the marriage agreement no other provisions are held ". ${ }^{2}$ From this article, it can be understood that starting from the moment of marriage, a unity of property applies unless the asset is separated by making a marriage agreement.

The concept of marriage assets in the Marriage Law is separate property, as in Article 35 paragraph (2) which states that "the inheritance of each sumi and wife and the assets obtained respectively as gifts and inheritance, are under the control each as long as the parties do not determine the others ". If based on this understanding, it can happen with a marriage agreement that actually adds to the wealth, because a separate inheritance can be promised differently in a marriage agreement. Differences in the concept of marriage property from the two laws also cause the concept of a marriage agreement to differ from the two laws.

In Indonesia, the phenomenon of existing marriage agreements has not been able to touch various circles and the implementation of the marriage agreement is still limited to certain circles, for example in the city of Mataram it is still rare for people to do a Marriage Agreement with the reasons, among others:

a. Because they consider marriage to be sacred, so if it is interfered only because of property problems it is considered unethical (considered taboo);

b. Lack of community knowledge regarding Marriage Agreements;

c. Still more adhering to customary law / customs (people accustomed to getting married without having to have any agreement forever)

In the Provisions regarding the authority of a Notary Public to make an authentic deed regulated in Law No. 30 of 2004 concerning the Position of Notary as amended by Law No. 2 of 2014 ("UUJN"). In Article 1 number 1 of the UUJN, it is stated that the Notary is a public official, authorized to make an authentic deed and has other authorities as referred to in this Act or based on other laws.

"Article 147 of the Civil Code also states that marital agreements must be made with a notarial deed before a marriage is held with a null sanction (nietig) and the agreement takes effect from the marriage between the husband and wife concerned. This contradicts the existing provisions in Marriage Law Number 1 of 1974 which does not clearly state whether a marriage agreement must be made with a notarial deed or simply by hand, the most important thing in a marriage agreement deed is the endorsement of a Marriage Registration Employee. There are several validity requirements in the marriage agreement, namely: ${ }^{3}$

1. To prevent haste, because the consequences of this agreement will be borne for life;

2. For legal certainty; As the only legal proof;

3. To prevent the possibility of smuggling the contents of the agreement

The rules regarding marriage agreements change completely after the Constitutional Court ruling Number 69 / PUU-XIII / 2015 which allows the making of marriage agreements can be done not only before marriage as stipulated in the Marriage Law Number 1 of 1974 concerning Marriage and Article 147 of the Book Civil Law Act But a marriage agreement can be made or carried out after the marriage.

Regarding the Constitutional Court's Decision Number 69 / PUU-XIII / 2015 regarding the permissibility of a marriage agreement made after the marriage, then the Constitutional Court's decision indirectly contradicts the

\footnotetext{
${ }^{1}$ Ibid. hal 14

${ }^{2}$ Indonesia Kitab Undang-Undang Hukum Perdata Lembaran Negara Nomor 23 Tahun 1847

${ }^{3}$ Salim H.S dan Erlies Septiana Nurbani, Penerapan Teori Hukum Pada Penelitian Tesis dan Disertasi, Raja Grafindo Persada, Jakarta, 2013, hlm. 17-18
} 
Civil Kit Act Article 149, 1320, and 1338. So the writer will examine more further on "The Role and Authority of Notary Public in Making Deed of Marriage Agreement According to Positive Law in Indonesia."

\section{Research methods}

The research method used is descriptive qualitative analysis. This type of research used in this study is empirical normative research. Approach techniques used ${ }^{1}$ include the Legislative Approach (Statue Approach), Conceptual Approach (Conceptual Approach), Sociological Approach (Sociological Approach). laws sorted by hierarchy, KUHP funds, and legislation; Secondary legal materials, such as: books, references in the form of scientific work, papers, magazines, doctrines (opinions, views); Tertiary legal materials, in this study used Indonesian dictionary, legal dictionary, and encyclopedia. Data collection techniques derived from library materials, field data in this study were collected by means of structured interviews or interviews using guide questions that have been prepared and carried out directly to several Notaries in Mataram.

\section{Results and discussion}

\section{Limits of Notary Authority in Making Deed of Marriage Agreement}

Notary, is a very important profession and is needed in society, bearing in mind the function of the Notary is to produce written evidence regarding authentic deeds, as stated in Article 1868 of the Civil Code. As for what is meant by an authentic deed based on Article 1868 of the Civil Code is: "An authentic deed is a deed which in the form determined by the law was made by or in front of public officials in power for that in the place where the deed was made".

In the case of making a deed, the notary is requested not to side with one of the people who came to him in carrying out legal actions, as stated in Article 16 paragraph (1), which reads:

"In carrying out his position, the Notary must: a. act trustworthy, honest, thorough, independent, impartial, and protect the interests of parties involved in legal actions ".

This authority is further elaborated in Article 1 of the Notary Position Regulation, Staatblad 1860 Ordinance number 3 which is effective from July 1, 1860 which is then renewed by Law number 30 of 2004, Article 1 point 1 which states "Notary is a public official authorized to make a deed authentic and other authorities as referred to in this Law".

The authority of a Notary Public according to this Law is regulated in Article 15 paragraph (1) which states that:

"The notary has the authority to make an authentic deed regarding all deeds, agreements and provisions required by the parties concerned to be stated in an authentic deed, guarantee the certainty of the date of making the deed, keep the deed, give the grosse, copy and quote the deed, all of it during the making of the deeds. not also assigned or excluded to other officials or other people determined by law ".

In addition to the limited wide authority, the Notary was also given another authority, as stipulated in Article 15 paragraph (2) letter e, namely the authority to provide legal counseling in connection with the drafting of the deed. Based on this provision, the Notary in carrying out his position must hold and refer to the applicable laws and regulations and must refuse to make a deed or provide other legal services that are not appropriate or even deviate from the applicable laws and regulations.

The validity of the Marriage Law, the marriage agreement must be made in a notarial manner (Article 147 of the Civil Code). Notary as a public official is subject to Notary Position Regulation (PJN), namely Ord, Stbl 1860 No. 3. Based on Article 1 the PJN states that the Notary Public is the only public official authorized to make an authentic deed regarding all deeds, agreements and stipulations required by a regulation the public or by interested parties are required to be stated in an authentic deed, guarantee the certainty of the date, keep the deed and provide the grose, copies and quotations, all as long as the making of the deed by a general regulation is not also assigned or excluded to officials or others. At this time the marriage agreement can be made in writing both notary and under the hand.

If the marriage agreement is made in a notary form, then the notary must make it, while the marriage agreement under the hand can be made by the parties without involving the notary public. Article 1 paragraph 1 of the UUJN states that notaries are public officials who are authorized to make authentic deeds and other authorities as referred to in this law.

The authority of a notary in making an authentic marriage agreement can be seen in Article 15 paragraph 1 that the Notary has the authority to make an authentic deed regarding all deeds, agreements, and provisions required by statutory regulations and / or desired by the parties concerned to be stated in the deed authentic, guaranteeing the certainty of the date of making the deed, keeping the deed, giving the grosse, copy and quote of the deed, all of it as long as the making of the deeds is not also assigned or excluded to other officials or others

\footnotetext{
${ }^{1}$ Salim H.S dan Erlies Septiana Nurbani, Penerapan Teori Hukum Pada Penelitian Tesis dan Disertasi, Raja Grafindo Persada, Jakarta, 2013,
} hlm. 17-18 
stipulated by law.

Furthermore Article 1870 of the Civil Code states that an authentic deed giving between the parties and their heirs or persons who have the rights from them is a perfect proof of what is contained therein. Authentic deed is a binding evidence in the sense that what is written in the deed must be trusted by the judge, that must be considered as true, as long as his untruth cannot be proven. An authentic deed provides perfect proof, meaning that it no longer needs additional proof, and is a binding and perfect proof. ${ }^{1}$

Other notary authorities are listed in Article 15 paragraph 2 letter a, which is to certify the signature and determine the certainty of the date of the letter under the hand by registering in a special book. An example is the marriage agreement deed made under the hand then the deed was legalized by a Notary. The legal basis that allows the drafting of a marriage agreement to be held under the hand is Article 10 paragraph 2 of the Decree of the Minister of Religion of the Republic of Indonesia Number 477 of 2004 concerning Marriage Registration as follows:

"The marriage agreement is made in 4 copies on sufficiently stamped paper according to statutory regulations; first sheet for husband, second for wife, third for Peghulu and fourth for Court ".

The notary obligation is a position obligation, because it legally requires the notary to provide assistance to anyone who needs services to him regardless of race, ethnicity, color, religion, culture, socio-economic, social or economic, rich or poor, political beliefs, gender, and ideology. The notary's obligation relates to private law, especially to make authentic deed regarding all deeds, agreements or stipulations required by a general regulation or by interested parties to be stated in an authentic deed. On the other hand, the authority of a notary public also in the field of public law is in accordance with his status and position as a public official.

As a general official, the deed made by a notary is authentic and has the strength of proof. As an authentic deed, it is usually stated in the marriage agreement that the hour on which the deed was made, at which time the deed was formalized. This is intended to make it clear that the deed was made before the marriage took place. ${ }^{2}$

As a notary, it is not permissible to refuse to provide assistance, including if he is asked to make an agreement such as a marriage agreement as stipulated in Part Two, Article 16 paragraph (1) letter d of the Law of Notary Office which reads:

"Provide services in accordance with the provisions of this Law, unless there is a reason to reject them".

The marriage agreement is part of the engagement, thus subject to Article 1320 of the Civil Code, and the notary who will make the marriage agreement deed must pay attention to the legal conditions of the agreement provided for in Article 1320 of the Civil Code.

It should also be stressed here, that the marriage agreement is a deed drawn up before (ten overstaan) notary or is a deed of party, where the notary only incorporates the marriage agreement deed what matters the parties want the party to pour into the marriage agreement. In this case, the notary is responsible for the formality of the deed, while the responsibility related to the contents of the deed is the parties concerned.

Article 147 of the Civil Code paragraph 1, the marriage agreement must be made with a notarial deed, this aims to protect the interests of the parties and also third parties, with the agreement made with the notarial deed, then the interests of third parties will be protected, even though it is different from what is determined in the Marriage Law. Wherein in Article 29 paragraph 1, the marriage agreement is made in writing with the mutual agreement of the two parties to the marriage. This Marriage Law marriage agreement can also be made under the hand.

In making a marriage agreement a special expertise is needed, namely the person making the marriage agreement must be someone who truly understands the law of marital property and can formulate all the beds or conditions in the deed with great care and conscience. This relates to the provision that the form of marital property in the family according to the Civil Code must remain throughout the marriage. The consequence is that a mistake in formulating a beding in a marriage agreement cannot be corrected during marriage. ${ }^{3}$

Deed of marriage agreement made with notarial deed is intended so that there is legal certainty, especially concerning the rights and obligations of husband and wife for their wealth, besides that it also aims to protect other parties with an interest in the existence of the marriage agreement. Often with the ignorance of a married couple when their home is in trouble, such as facing divorce, they come before a notary to make the deed of distribution of assets, they consider it as a marriage agreement.

Facing such comparisons, this is where the notary's role and responsibility are required in making the deed of agreement, whereby anyone can make any agreement, as long as it meets the requirements of Article 1320 of the Civil Code and is not prohibited, the notary may not refuse to make the deed requested by his client.

In terms of making a marriage agreement, the responsibility of the notary is limited to the formality of the deed he made, because as a party deed, the parties are responsible for the contents and purpose of the agreement deed, while the notary as a public official is only authorized to pour into his deed what be their will and agreement.

\footnotetext{
${ }^{1}$ Subekti, hal. 27

${ }^{2}$ G.H.S Lumban Tobing, hal. 186

${ }^{3}$ Satrio, hal. 153
} 
As stated in Article 29 of the Marriage Law, that a marriage agreement can be changed, as long as it does not harm a third party, it is up to the notary to safeguard his interests in carrying out his duties and authority, then in the agreement must include a clause stating that if there is a change in the marriage agreement mentioned, the notary is only responsible for the making of the deed. Whereas the content of the deed is the responsibility of the parties to the deed (the parties), it aims to avoid undesirable legal consequences that can harm the notary in the future.

Thus we can conclude that the authority and responsibility of a notary in making the deed he made is limited to the contents of the agreement that has fulfilled the legal requirements of the agreement under Article 1320 of the Civil Code, so he cannot be prosecuted in court. Conversely, if a contract is not fulfilled, then the deed made by a notary can be canceled by the judge. Cancellations decided by a judge on a notarial deed can be in the form of (1) null and void; or (2) can be canceled.

Notary as a noble and dignified profession, of course, must be careful in pouring the contents of the deed desired by the parties. The issue of the validity of the identity and the object promised must be seen by itself as formal and material data before the deed is made and signed. For this reason, before making a notarial marriage agreement, the trust and trust of the identity of the parties as well as the object / property promised must be clear.

The elaboration of Notary authority as a Public Official includes, among others, Article 15 paragraph (1) which reads:

"The notary has the authority to make authentic deeds regarding all deeds, agreements and provisions required by statutory regulations and or as desired by the parties concerned to be stated in the authentic deed guaranteeing the certainty of the date of making the deed, keeping the deed, giving the gross, copies and quotations, all of which are of interest. as long as the making of the deeds is also not assigned or excluded to other officials or other people determined by law."

A.W. Voor divides the work of a Notary Public into 2 parts, namely: ${ }^{1}$

1. Legal work, which is work that is ordered by law. This work is a duty as an official to carry out some of the Government's powers, including:

a) Provides legal certainty;

b) Creating a grosse that has an executorial power;

c) Give a statement in a deed that replaces the signature;

d) Giving a certificate regarding someone's signature.

2. Extra legal work, that is work entrusted to him in that position. This work is another task entrusted to him to guarantee and maintain "Protection of legal certainty" in the sense that every person has rights and obligations that cannot be reduced or just eliminated either because they are underage or suffering from a memory disease. it is required by law and this is evidence of the confidence of lawmakers in a notary public.

Legal and extra-legal work can only be carried out by a profession that is people who have special expertise and with that expertise can carry out legal and extra-legal job functions. Based on the provisions of Article 1868 of the Civil Code and the opinions of the Law and legal experts concerning Public Officials, it can be concluded that Public Officials must meet the following criteria:

a) Public Officials must be independent state organs;

b) The authority of the Public Official to make an authentic deed regarding all acts, agreements and stipulations in the civil service field, except by general regulations Notary is declared not authorized or co-authorized with other officials; General rules, (algemene verordening) means laws, so that the authority of public officials must be regulated in the form of laws;

c) Ensuring the certainty of the date;

d) Keep the original deed;

e) Give gross, copies and quotes.

\section{Conclusion}

Law Number 1 of 1974 Marriage regarding marriage agreements; the law only stipulates in article 29, as follows:

1. At the time or before the marriage takes place, both parties with mutual agreement can enter into a written agreement that is ratified by the marriage registrar, after which the contents also apply to third parties as long as the third party is involved.

2. The agreement cannot be ratified if it violates the limits of law, religion, and decency.

3. The agreement will take effect since the marriage takes place.

4. During the marriage the agreement is not changed, except if both parties have an agreement to change and the change does not harm a third party.

Article 149 of the Civil Code explicitly stipulates that "After the Marriage takes place, the Marriage Agreement in any way, may not be changed". The sound of the article means that according to the provisions

\footnotetext{
${ }^{1}$ Tan Thong Kie, Op. Cit., hal. 165-166.
} 
contained in the Civil Code, married couples who have made a Marriage Agreement are not permitted or prohibited from making changes to the contents of the Marriage Agreement after their marriage takes place.

Decision of the Constitutional Court Number 69 / PUU-XIII / 2015 that allows the making of marriage agreements can be done not only before marriage as stipulated in the Marriage Law Number 1 of 1974 concerning Marriage and Article 147 of the Civil Code but can be made or a marriage agreement is made after the marriage. Indirectly the Mahkama constitutional decision opened up opportunities for wives and husbands to renew or reconstruct the contents of the marriage agreement because the ruling provided room for this.

\section{Limits of Notary Authority in Making Deed of Marriage Agreement}

The authority of a Notary Public according to this Law is regulated in Article 15 paragraph (1) which states that: "The Notary has the authority to make an authentic deed regarding all deeds, agreements and provisions required by the parties concerned to be stated in an authentic deed, guaranteeing the certainty of the date of making the deed, keep the deed, give the grosse, copy and quote the deed, all of it as long as the making of the deeds are not also assigned or excluded to other officials or others stipulated by law ".

In the case of making a deed, the notary is requested not to side with one of the people who came to him in carrying out legal actions, as stated in Article 16 paragraph (1), which reads: "In carrying out his position, the Notary must: a. act trustworthy, honest, thorough, independent, impartial, and protect the interests of parties involved in legal actions ".

\section{Suggestion}

1. For brides who want to make a marriage agreement or prenuptial agreement should include in the clause of the marriage agreement include, among others, such as "can be changed during the marriage". With this, during the marriage both parties can be reconstructed the contents of the marriage agreement. If there is no clause that can change the contents of the marriage agreement then the agreement cannot be changed as stated in the law.

2. For notaries not to side with one of the parties in making the contents of the agreement. The notary is expected to be passive but active when the matters presented by the parties do not comply or violate the provisions of the applicable laws and regulations.

\section{References}

Abdullah Wiwiek Wahyuningsih, Perancang Kontrak \& Memorandum of Understanding (MoU), (CetakanIII; Jakarta: Sinar Grafika, 2008).

Ali Achmad , 2002. Menguak Tabir Hukum (Suatu Kajjian Filosofi dan Sosiologis), Toko Gunung Agung, Jakarta. Asshiddiqie Jimly, 2007. Pokok-Pokok Hukum Tata Negara Indonesia Pasca Reformasi, Bhuana Ilmu Popular, Jakarta.

Ghozali Abdul Rahman, 2012. Fiqh Munakahat, Kencana, Cet. Ke Lima, Jakarta.

Masyitha Putri Awaliah. 2012. Harta Bersama yang diserahkan kepada Anak setelah Perceraian (Studi Kasus No. 346/Pdt.G/2010/PA.Smg). Skripsi Fakultas Hukum Universitas Hasanudin Makasar.

Hadjon Philipus M., 1987. Perlindungan Hukum Bagi Rakyat Di Indonesia Sebuah Studi Tentang PrinsipPrinsipnya, Penanganannya Oleh Pengadilan Dalam Lingkungan Peradilan Umum Dan Pembentukan Peradilan Administrasi Negara, Bina Ilmu, Surabaya.

Hasil wawancara dengan Jeni Deni Supriadi, SH.,Pengacara yang berkantor di Kota Mataram, tanggal 11 Desember 2019, Jam 18.00 WIB

HS Salim, 2003. Hukum Kontrak Teori \& Teknik Penyusunan Kontrak, Sinar Grafika, Jakarta.

HS Salim dan Erlies Septiana Nurbani, Penerapan Teori Hukum Pada Penelitian Tesis dan Disertasi, Raja Grafindo Persada, Jakarta, 2013.

http//:digilib.unila.ac.id. Konsep-perkainan-di-indonesia. Diakses Pada Tanggal 2 desember 2019, Pukul. 21.10 WITA

Isnaeni Moch. Hukum Perkawinan Indonesia, Revka Petra Media, Surabaya, 2016,

Kansil Cst, dkk, Kamus Istilah Hukum, Jala Permata Aksara, Jakarata, 2009,

Manan Bagir, 1994. Dasar-Dasar Sistem Ketatanegaraan Republic Indonesia Menurut UUD 1945, Bandung.

Dominikus Rato,filsafat Hukum Mencari dan Memahami Hukum, PT PresindoYogyakarta, 2010,

Manan Bagir, 2003. Teori Dan Politik Konstitusi, UII Perss, Jakarta. Hal. 238-239

Gautama Sudargo, 1983. Pengertian Tentang Negara Hukum, Alumni, Bandung.

Martosoewignj Sri Soemantri, 1992. Dasar-Dasar Sistem Ketatanegaraan Republic Indonesia Menurut UUD 1945, Alumni, Bandung.

Mertokusumo Sudikno, 1988. Hukum Acara Perdata di Indonesia, Liberty, Yogyakarta.

Prawirohamidjojo R. Soetojo, 2002. Pluralisme dalam PerundangUndangan Perkawinan di Indonesia, Surabaya: Airlangga University Press.

Syahrani Riduan, 2000. Seluk Beluk dan Asas-asas Hukum Perdata, Alumni, Bandung.

Prawirohamidjojo R. Soetojo, 1988. Pluralisme dalam Perundang-undangan Perkawinan di Indonesia, Airlangga 
University Press.

Syafioedin M, 2011. Hisyam, Metode Penelitian Hukum, Fakultas Hukum Universitas Brawijaya Malang.

Yuvens, 2017. Critical Analysis on Marital Agreement in the Decision of Constitutional Court Number 69/PUUXIII/2015. Jurnal Konstitusi, Volume 14, Nomor 4, Desember 2017 